\title{
Molecular Detection of the Adult Plant Leaf Rust Resistance Gene Lr34 in Romanian Winter Wheat Germplasm
}

\author{
M. CiucA*, D. Cristina, A.G. Turcu, E.L. Contescu, V. IOnescu and N.N. SAulescu
}

National Agricultural Research and Development Institute, Fundulea, 915200, Romania

(Received 4 June 2014; Accepted 22 July 2014;

Communicated by J. Kolmer)

\begin{abstract}
Wheat continues to be one of the most cultivated cereals in the world, and also in Romania. Leaf rust caused by Puccinia triticina reduces the wheat yield and grains quality worldwide. In the context of climate change, leaf rust has become a more important problem for both wheat growers and breeders in our country. Use of genetic resources, carrying rust resistance genes, play an important role in breeding programs leading to resistant varieties, which can have positive impact on environment and economy. Therefore, the identification of resistance genes in modern wheat cultivars and breeding lines, and then selection of the best resistance genes combination(s) are the first steps for a successful breeding program. At present, one of the best known and studied adult plant leaf rust resistance gene is Lr34 that contributes significantly to durable leaf rust resistance. The functional markers that enable early detection of this gene are a major advantage in the wheat breeding.

The aim of this study was to evaluate the presence of the slow rusting resistance gene $\operatorname{Lr} 34$ in Romanian wheat germplasm, using cssfr4 and cssfr5 molecular markers. Screening of 47 winter bread wheat cultivars and 47 breeding lines with these markers showed the presence of the Lr34 resistant haplotype in 62\% (homozygous genotypes) of the total genotypes. A high frequency ( $79 \%$ ) of $L r 34$ resistance allele was found among 47 breeding lines, suggesting that maintenance of a high frequency of this allele represents a real advantage for the development of adult plant resistance in Romanian breeding programs.
\end{abstract}

Keywords: molecular detection, molecular markers, adult plant leaf rust resistance, $\operatorname{Lr} 34$ gene

\section{Introduction}

Wheat is an important cereal in the world. In Romania wheat plays an important role in the national economy, being grown on about 2 million hectares and its production was 7.4 million tons in 2013 (Anonymous 2014). A limiting factor in the world wheat production is represented by diseases, such as rusts, smuts, powdery mildews, etc. In the context of climate change, at present, in Romania the rusts continue to be a problem for wheat production and so, a renewed challenge for breeders is to obtain new rust resistant cultivars,

* Corresponding author; E-mail: mcincda@gmail.com 
because growing of tolerant/resistant cultivars is an effective way of protecting crops against pathogens. Among rusts (leaf, yellow and stem rust), the leaf rust or brown rust, caused by Puccinia triticina Eriks., is currently one of the most frequent wheat diseases.

At present over 70 leaf rust resistance genes $(L r)$ have been mapped in wheat (Singh et al. 2013). Most of them confer race-specific resistance, acting in "gene for gene" manner as seedling plant resistance genes, but the resistance provided by these genes can be short-lived as new races of the pathogen appear. There are a few $L r$ genes that confer non-race-specific resistance, acting at the adult plant stage (APR - Adult Plant Resistance), as partial resistance. This small group of leaf rust resistance genes is named "slow-rusting" group; although, their effect is smaller than that of the race-specific genes they had remained durable in time (Singh et al. 2003; Lagudah 2011). The effect of slow-rusting genes is also more dependent on environmental conditions. The best known slow-rusting Lr genes are Lr34 (Dyck 1977), Lr46 (Singh et al. 1998), Lr67 (Hiebert et al. 2010; Herrera Foessel et al. 2011) and Lr68 (Herrera Foessel et al. 2012).

One of the well-known and characterized race-non-specific resistance genes is the adult plant leaf rust resistance gene $\operatorname{Lr34}$. This gene was described by Dyck (1977), as LrT2, in the cultivar Frontana and was located on short arm of the chromosome 7DS (Dyck 1987). Lr34 or closely linked genes was found to provide resistance to two other rust diseases (Singh et al. 2012) and powdery mildew (Spielmeyer et al. 2005; Lillemo et al. 2008). Recently, this locus has been also shown to provide resistance to spot blotch caused by Bipolaris sorokiniana (Lillemo et al. 2013). In addition, Lr34 was reported to be associated with LTN ( $L t n 1$; Singh 1992) and Bdv1. Another important reported feature of $L r 34$ is that this gene combined with $L r$ genes such as $\operatorname{Lr} 13, \operatorname{Lr} 37$ (German and Kolmer 1992; Kloppers and Pretorius 1997) and $\operatorname{lm}$ (lesion mimic) enhances wheat resistance to leaf rust (Li et al. 2012).

Resistant and susceptible haplotypes of the $\operatorname{Lr} 34$ gene have been identified (Krattinger et al. 2009). The resistant haplotype of Lr34 is characterized by a 3 bp deletion (TTC) in exon 11 and a SNP (T to C) in exon 12. At present, several molecular markers for alleles of Lr34 gene are available (Lagudah et al. 2009; Dakouri et al. 2010), and can be used in marker assisted selection in breeding programs.

Previous research identified the presence of Lr34 resistance allele in some Romanian cultivars, using PCR markers, noting that this allele is very frequent in Romanian wheat germplasm (Purnhauser et al. 2011). In this paper, we aimed to characterize a larger collection of Romanian winter wheat cultivars and breeding lines for allelic variation at $L r 34$ locus, using both the tightly linked marker csLV34 and functional molecular markers.

\section{Materials and Methods}

\section{Plant material}

Ninety-four Romanian winter wheat genotypes, including forty-seven bread wheat cultivars released in Romania during the last 81 years (Table 1) and forty-seven breeding lines, were included in this study. Three wheat genotypes, namely Chinese Spring 
Table 1. Molecular markers characterization of leaf rust resistance gene Lr34 in Romanian winter wheat cultivars

\begin{tabular}{|c|c|c|c|c|c|}
\hline \multirow[t]{2}{*}{$\begin{array}{l}\text { Nr. } \\
\text { crt. }\end{array}$} & \multirow[t]{2}{*}{ Wheat variety } & \multirow[t]{2}{*}{ Genealogy } & \multirow[t]{2}{*}{$\begin{array}{l}\text { Released } \\
\text { (Year) }\end{array}$} & \multicolumn{2}{|c|}{$\begin{array}{l}\text { Molecular } \\
\text { markers }\end{array}$} \\
\hline & & & & $\operatorname{csLV} 34$ & Cssfr5 \\
\hline 1 & A15 & Sel Tenmarq & 1933 & $\mathrm{a}$ & $\mathrm{Lr}-$ \\
\hline 2 & Odvos 241 & Sel Champlain & 1933 & $\mathrm{a}$ & $\mathrm{Lr}-$ \\
\hline 3 & Bucuresti 1 & Kanred/Tiganesti & 1962 & $\mathrm{a}$ & $\mathrm{Lr}-$ \\
\hline 4 & Dacia & Bucuresti1/Skorospelka3 & 1971 & $\mathrm{a}$ & $\mathrm{Lr}-$ \\
\hline 5 & Ceres & Miciurinka/Bezostaya1 & 1974 & $\mathrm{a}$ & $\mathrm{Lr}-$ \\
\hline 6 & Diana & Fiorello/Bezostaya1 & 1976 & $\mathrm{a}$ & $\mathrm{Lr}-$ \\
\hline 7 & Doina & Et.Choisy/Monon & 1977 & $\mathrm{a}$ & $\mathrm{Lr}-$ \\
\hline \multirow[t]{2}{*}{$\begin{array}{l}\mathrm{Nr} . \\
\text { crt. }\end{array}$} & Wheat variety & Genealogy & $\begin{array}{l}\text { Released } \\
\text { (Year) }\end{array}$ & \multicolumn{2}{|c|}{$\begin{array}{l}\text { Molecular } \\
\text { markers }\end{array}$} \\
\hline & & & & csLV34 & Cssfr5 \\
\hline 8 & Fundulea 29 & Aurora/Riley67 & 1979 & $\mathrm{a}$ & $\mathrm{Lr}-$ \\
\hline 9 & Fundulea 133 & SWW7/PRIBOI & 1985 & $\mathrm{a}$ & $\mathrm{Lr}-$ \\
\hline 10 & Simnic 30 & Sel Diana & 1987 & $\mathrm{a}$ & $\mathrm{Lr}-$ \\
\hline 11 & Trivale & Er397H66/DACIA & 1991 & a & $\mathrm{Lr}-$ \\
\hline 12 & Apullum & Odesskaia75/Bezostaya1 & 1992 & $\mathrm{a}$ & $\mathrm{Lr}-$ \\
\hline 13 & Fundulea 4 & Fundulea29/2*Lovrin 32 & 1994 & $\mathrm{a}$ & $\mathrm{Lr}-$ \\
\hline 14 & Turda 95 & F199I1-2/T6-80-86 & 1995 & $\mathrm{a}$ & $\mathrm{Lr}-$ \\
\hline 15 & Zimbru & Fundulea 4Sib/F154I1-1//Aniversar/Roxana & 1998 & $\mathrm{a}$ & Lr- \\
\hline 16 & Gasparom & Sv 9710-79/Fundulea 4 & 1998 & $\mathrm{a}$ & $\mathrm{Lr}-$ \\
\hline 17 & Esential & Sv2946-86/Sv9710-78 & 2001 & a & $\mathrm{Lr}-$ \\
\hline 18 & Dumbrava & 603106/Flamura85//F2416W2-12/Fundulea4 & 2003 & $\mathrm{a}$ & $\mathrm{Lr}-$ \\
\hline 19 & Crisana & Fundulea4/Atlas66 & 2005 & $\mathrm{a}$ & $\mathrm{Lr}-$ \\
\hline 20 & Miranda & ERYT26221/96869G1-1//GLOSA & 2010 & $\mathrm{a}$ & $\mathrm{Lr}-$ \\
\hline 21 & Otilia & F96052G16-2/FAUR & 2014 & $\mathrm{a}$ & $\mathrm{Lr}-$ \\
\hline 22 & Suceava 84 & Bezostaya1/F208 & - & a & $\mathrm{Lr}-$ \\
\hline 23 & Excelsior & Bucuresti1/Skorospelka3 & 1971 & $\mathrm{H}$ & $\mathrm{H}$ \\
\hline 24 & Favorit & Bezostaya1/Odvos241 & 1971 & $\mathrm{H}$ & $\mathrm{H}$ \\
\hline 25 & Iulia & Bezostaya1/Beloterkovsk198 & 1974 & $\mathrm{H}$ & $\mathrm{H}$ \\
\hline 26 & Simnic 50 & $\begin{array}{l}\text { Lovrin32/Fundulea29/F553D4- } \\
\text { 22/3/1502W23-1/4/Donskaia Polukarlikovaya }\end{array}$ & 2004 & $\mathrm{H}$ & $\mathrm{H}$ \\
\hline 27 & Lovrin 34 & Ranniaia12/Nadadores63//Lovrin 12 & 1981 & $\mathrm{~b}$ & $\mathrm{Lr}+$ \\
\hline 28 & Transilvania 1 & US(60)43/Avrora//T141-65 & 1981 & $\mathrm{~b}$ & $\mathrm{Lr}+$ \\
\hline 29 & Ariesan & Rubin/T141 & 1985 & $\mathrm{~b}$ & $\mathrm{Lr}+$ \\
\hline 30 & Aniversar & Lv11/F53-67 & 1986 & $\mathrm{~b}$ & $\mathrm{Lr}+$ \\
\hline 31 & Flamura 85 & JUWEL/Lv32A//2*FL80 & 1989 & $\mathrm{~b}$ & $\mathrm{Lr}+$ \\
\hline 32 & Rapid & Juwel/Lv32A//2*FL80 & 1992 & $\mathrm{~b}$ & $\mathrm{Lr}+$ \\
\hline 33 & Dropia & COLOTANA/2120W1 & 1993 & $\mathrm{~b}$ & $\mathrm{Lr}+$ \\
\hline 34 & Alex & Flamura80/Fundulea29 & 1994 & $\mathrm{~b}$ & $\mathrm{Lr}+$ \\
\hline 35 & Ardeal 1 & F48212-112/F2098W1 & 1999 & $\mathrm{~b}$ & $\mathrm{Lr}+$ \\
\hline 36 & Boema 1 & F308O2-20/DROPIA & 2000 & $\mathrm{~b}$ & $\mathrm{Lr}+$ \\
\hline 37 & Crina & F309O3-0/4141W1-1 & 2001 & $\mathrm{~b}$ & $\mathrm{Lr}+$ \\
\hline
\end{tabular}




\begin{tabular}{|c|c|c|c|c|c|}
\hline \multirow[t]{2}{*}{$\begin{array}{l}\mathrm{Nr} . \\
\text { crt. }\end{array}$} & \multirow[t]{2}{*}{ Wheat variety } & \multirow[t]{2}{*}{ Genealogy } & \multirow[t]{2}{*}{$\begin{array}{l}\text { Released } \\
\text { (Year) }\end{array}$} & \multicolumn{2}{|c|}{$\begin{array}{c}\text { Molecular } \\
\text { markers }\end{array}$} \\
\hline & & & & $\operatorname{csLV} 34$ & Cssfr5 \\
\hline 38 & Delabrad2 & 308O2-20/DROPIA & 2002 & $\mathrm{~b}$ & $\mathrm{Lr}+$ \\
\hline 39 & Dor F & F151M1-1/F2076W12-11// F4105W2-1 & 2002 & $\mathrm{~b}$ & $\mathrm{Lr}+$ \\
\hline 40 & Faur F & F307P2-1101/F135U2-1 & 2004 & $\mathrm{~b}$ & $\mathrm{Lr}+$ \\
\hline 41 & Gruia & AF93-2/F135U2-1 & 2005 & $\mathrm{~b}$ & $\mathrm{Lr}+$ \\
\hline 42 & Glosa & F135U2-1/F508U1-1BUCUR & 2005 & $\mathrm{~b}$ & $\mathrm{Lr}+$ \\
\hline 43 & Izvor & KARL/F201R2-111//F508U1-1 & 2008 & $\mathrm{~b}$ & $\mathrm{Lr}+$ \\
\hline 44 & Litera & ERYT26221/F96869G1-1// GLOSA & 2009 & $\mathrm{~b}$ & $\mathrm{Lr}+$ \\
\hline 45 & Pajura & IZVOR/F96012G2-2//GLOSA & 2014 & $\mathrm{~b}$ & $\mathrm{Lr}+$ \\
\hline 46 & Ostrov & IZVOR/F95272G1-11 & $\begin{array}{l}\text { under official } \\
\text { testing }\end{array}$ & $\mathrm{b}$ & $\mathrm{Lr}+$ \\
\hline 47 & Pitar & 02555GP2/00099GP2 & $\begin{array}{l}\text { under official } \\
\text { testing }\end{array}$ & $\mathrm{b}$ & $\mathrm{Lr}+$ \\
\hline
\end{tabular}

Notes: H heterozygous/heterogenic; Lr+ Lr34 resistant allele; Lr- Lr34 susceptible allele

(Lr34+), nulli-tetrasomic 7D7A (N7DT7A) line of Chinese Spring and Thatcher (non- $\operatorname{Lr} 34$ ), were used as controls, in order to confirm the presence or absence of specific Lr34 alleles using molecular markers.

\section{DNA extraction and PCR analysis for Lr34 alleles}

For extraction of genomic DNA, 10 embryos rescued from each tested genotype were ground with $1 \mathrm{ml}$ extraction buffer (sorbitol 2.5\%, sarkosyl 1\%, sodium chloride 5\%, sodium-EDTA $0.8 \%$, CTAB $2 \%$, all reagents were dissolved into Tris $0.2 \mathrm{M}, \mathrm{pH} 8$ ) preheated at $65^{\circ} \mathrm{C}$. The ground material was transferred into $2 \mathrm{ml}$ tubes; after that, the tubes were incubated in water bath at $65^{\circ} \mathrm{C}$, for one hour. Then, the tubes were cooled at room temperature and $1 \mathrm{ml}$ chloroform: isoamyl alcohol (24:1) was added; the tubes were mixed by inversion 1-2 min and centrifuged $10 \mathrm{~min}$ at $8000 \mathrm{rpm}$. After that, the supernatant was transferred into a new tube and treated with chloroform:isoamyl alcohol (24:1) and centrifugation were repeated. After centrifugation the supernatant was transferred into a new tube and sodium chloride $5 \mathrm{M}$ at $0.25 \mathrm{M}$ final concentration and $2.5 \mathrm{vol}$. of cold absolute ethanol were added. The tubes were centrifuged $5 \mathrm{~min}$ at $13000 \mathrm{rpm}$ and after that the supernatant was discarded and DNA pellet was washed with $400 \mu$ wash buffer ( $76 \%$ absolute ethanol and $10 \mathrm{mM}$ ammonium acetate). The tubes were again centrifuged $3 \mathrm{~min}$ at 14,000 rpm, the supernatant was discarded and the pellet was dried and $100 \mu \mathrm{TE}$ (Tris $10 \mathrm{mM}$ and EDTA $1 \mathrm{mM}$ ) was added in tube. DNA was checked in agarose gel $0.8 \%$ and with a spectrophotometer (DU730-Beckman Coulter). Genomic DNA was diluted to $20 \mathrm{ng} / \mu 1$ for each tested genotype.

For PCR analysis regarding the Lr34 alleles, we used 2 functional markers and one STS - csLV34 marker by Lagudah et al. (2006) and Lagudah et al. (2009): multiplex cssfr4 
Table 2. PCR markers used in this study

\begin{tabular}{|c|c|c|c|c|}
\hline $\begin{array}{l}\text { Primers } \\
\text { name }\end{array}$ & $\begin{array}{l}\text { Markers- } \\
\text { common } \\
\text { name }\end{array}$ & Primers sequence & $\begin{array}{l}\text { Size of PCR } \\
\text { product (bp) } \\
\quad L r 34+\end{array}$ & $\begin{array}{c}\text { Size of PCR } \\
\text { product (bp) } \\
\text { non- } \operatorname{Lr} 34\end{array}$ \\
\hline L34MINUSR & \multirow[t]{4}{*}{ Cssfr4 } & 5'TTGATGAAACCAGTTTTTTTTCTA 3' & - & 523 \\
\hline $\begin{array}{l}\text { L34DINT9F } \\
\text { (cssfr2) }\end{array}$ & & 5'TATGCCATTTAACATAATCATGAA3' & & \\
\hline csLV34-F & & 5'GTTGGTTAAGACTGGTGATGG3' & 150 & 229 \\
\hline csLV34-R & & 5'TGC TTG CTA TTG CTG AAT AGT3' & & \\
\hline L34DINT13R2 & \multirow[t]{4}{*}{ Cssfr5 } & 5'ACTTTCCTGAAAATAATACAAGCA 3' & 751 & - \\
\hline L34SPF & & 5'GGGAGCATTATTTTTTTCCATCATG 3' & & \\
\hline L34MINUSR & & 5'TTGATGAAACCAGTTTTTTTTCTA 3' & - & 523 \\
\hline $\begin{array}{l}\text { L34DINT9F } \\
\text { (cssfr2) }\end{array}$ & & 5'TATGCCATTTAACATAATCATGAA 3' & & \\
\hline
\end{tabular}

(cssfr2 (L34DINT9F/L34MINUS) with csLV34 marker) and multiplex cssfr5 (cssfr2 with L34SPF/L34DINT13R2) (Table 2).

All amplification reactions were carried out in a $25 \mu \mathrm{l}$ volume containing $1 \times$ buffer (AmpliTaq 360 DNA polymerase kit), $0.2 \mathrm{mM}$ dNTPs, $0.4 \mu \mathrm{M}$ for primers: L34DINT9F/ L34MINUS and L34SPF/L34DINT13R2 and $0.2 \mu \mathrm{M}$ for primers of csLV34 marker, $0.625 \mathrm{U}$ of DNA polymerase, $1.5 \mathrm{mM}$ magnesium chloride (1.8 $\mathrm{mM}$ magnesium chloride for cssfr5 marker), $100 \mathrm{ng}$ genomic DNA and $0.8 \mu \mathrm{l}$ of $360 \mathrm{GC}$ enhancer solution. The following amplification parameters were used: initial denaturation at $94{ }^{\circ} \mathrm{C}-3 \mathrm{~min}$, and then 35 cycles of $94{ }^{\circ} \mathrm{C}-1 \mathrm{~min}, 58^{\circ} \mathrm{C}-1 \mathrm{~min}, 72{ }^{\circ} \mathrm{C}-2 \mathrm{~min}$ and with final extension $72{ }^{\circ} \mathrm{C}-10$ min. PCR was performed in Gene Amp PCR system 9700 thermal cycler. The PCR products were separated on $1.5 \%$ agarose for routine use, in $0.5 \times$ TBE buffer, stained with ethidium bromide and photographed under ultraviolet light with Vilber Lourmat system.

\section{Results}

The multiplex PCR based on primers combination cssfr4 with csLV34 and cssfr2 (L34DINT9F/L34MINUS) (Lagudah et al. 2009) amplified three products; the $150 \mathrm{bp}$ product is the csLV34 "b" allele that is diagnostic of the Lr34 resistant haplotype, indicating the likely presence of the $L r 34$ resistance allele in genotypes carrying this gene. Two other products $229 \mathrm{bp}$ and $523 \mathrm{bp}$ are amplified, indicating genotypes not carrying the resistance allele of the $\operatorname{Lr} 34$ gene. The $229 \mathrm{bp}$ fragment is the csLV34 "a" allele and the 523 bp fragment belongs to the susceptible haplotype that lacks $L r 34$.

In genotypes that are heterozygous all three fragments are present, while in genotypes that are homozygous for resistance allele only one fragment (150 bp - csLV34 "b") is present and in genotypes that are homozygous for susceptible allele two fragments (229 bp - csLV34 "a" and 523 bp) are present (Fig. 1).

The result of the second multiplex PCR based on primer combination cssfr5 (L34SPF/ L34DINT13R2 and L34DINT9F/L34MINUS), consisted of two products: 751 bp product 


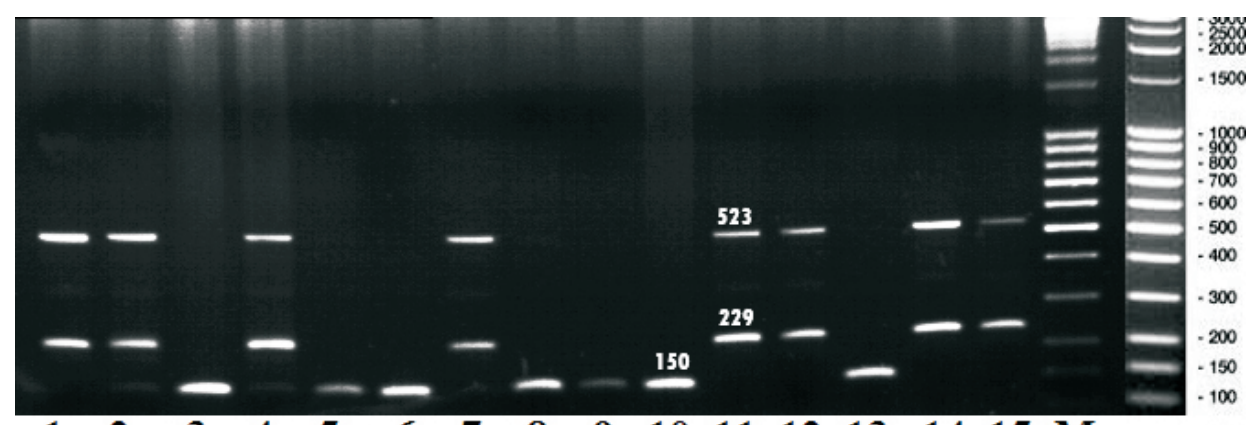

$\begin{array}{lllllllllllllllll}1 & 2 & 3 & 4 & 5 & 6 & 7 & 8 & 9 & 10 & 11 & 12 & 13 & 14 & 15 & \text { M }\end{array}$

Figure 1. Electrophoretic pattern obtained with cssfr4 marker. 1. Thatcher; 2. A15; 3. Dropia; 4. Ceres; 5. Izvor; 6. Glosa; 7. Bucuresti1; 8. Litera; 9. Pitar; 10. Partener; 11. Miranda; 12. Otilia; 13. Chinese Spring; 14. Diana; 15. Fundulea 4. M- 100 bp-DNA-Ladder extended (Roth)

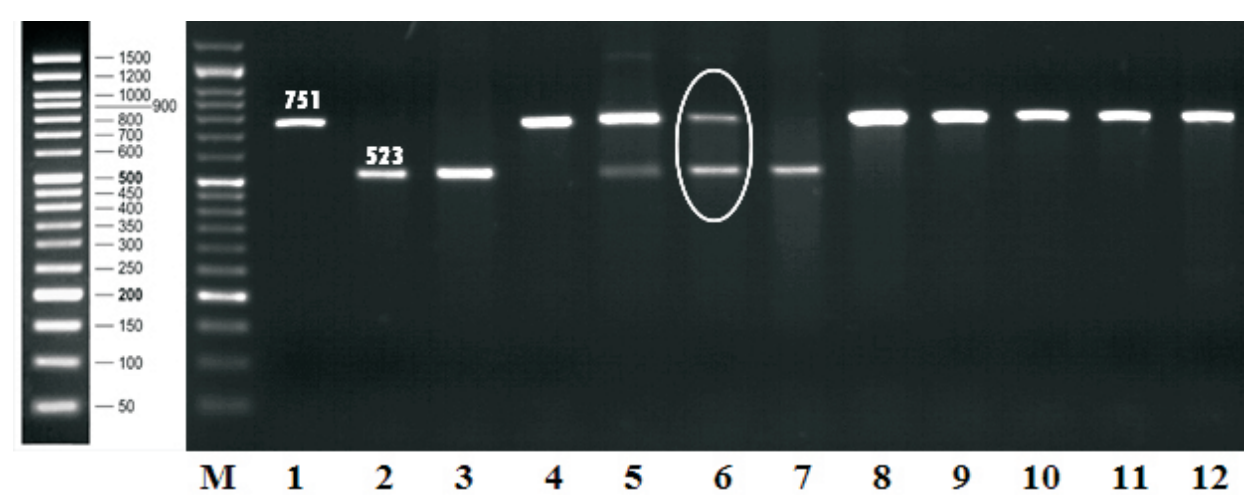

Figure 2. Electrophoretic pattern obtained with cssfr5 marker. M - 50 bp (GeneDirex); 1. Chinese Spring; 2. Thatcher; 3. Dacia; 4. Boema 1; 5. Favorit; 6. Line 08145G; 7. Doina; 8. Rapid; 9. Lovrin34; 10. Flamura $85 ; 11$. Alex; 12. Dor F

specific for $\operatorname{Lr} 34$ resistant haplotype and 523 bp, aforementioned, for $\operatorname{Lr} 34$ susceptible haplotype (Fig. 2).

The csLV34 marker is tightly linked to Lr34 gene, about $0.4 \mathrm{cM}$ distance (Lagudah et al. 2006) and the cssfr2 and cssfr5 are functional markers that were developed around the sequence changes in exon 11 (Lagudah et al. 2009).

Of the 94 Romanian investigated genotypes, 29 showed the presence of the $229 \mathrm{bp}$ and/or 523 bp in both multiplex reactions; therefore, the 29 genotypes are homozygous for Lr34 susceptible allele. Molecular detection showed 65 genotypes with Lr34 resistance allele. These 65 genotypes were divided into three groups:

- 6 genotypes were heterozygous (or heterogenic because the DNA isolation was made from 10 seeds) according to both multiplex reactions; 
- one genotype line $08145 \mathrm{G}$ was heterozygous for cssfr5 multiplex reaction (Fig. 2) but not for csLV34 marker from cssfr4 multiplex reaction. This line, showed only two bands (150- and 523-bp), and no 229-bp band for csLV34 "a" allele (Fig. 3); This result suggested a recombination between $L r 34$ gene and csLV34 marker locus for one chromosome.

- 58 genotypes homozygous for Lr34 resistance allele, according to both markers; $150 \mathrm{bp}$ and $751 \mathrm{bp}$ bands were present.
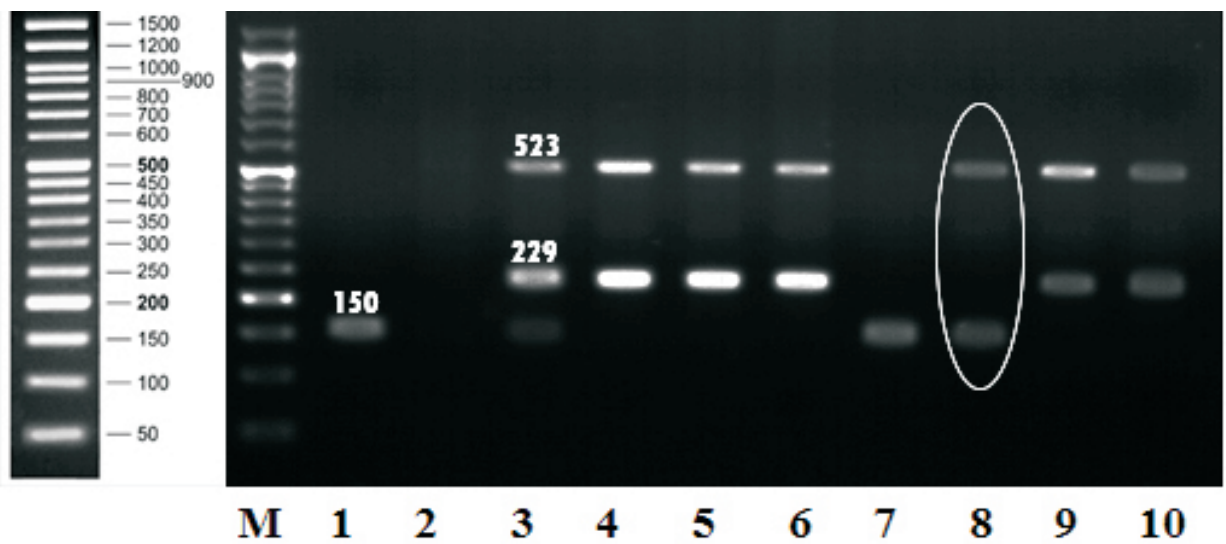

Figure 3. Electrophoretic pattern obtained with cssfr4 marker. M- 50 bp (GeneDirex); 1. Chinese Spring; 2. N7DT7A; 3. Favorit; 4. Simnic 30; 5. Trivale; 6. Apullum; 7. Izvor; 8. line 08145G; 9. Turda 95;

10. Zimbru. The circle shows the recombination between csLV34 marker and Lr34 gene

Molecular detection, using molecular markers, in the 94 analyzed Romanian genotypes, identified 58 genotypes homozygous for $\operatorname{Lr} 34$ resistant haplotype, representing a frequency of $62 \%$. Regarding the Romanian cultivars analyzed, the homozygous $\operatorname{Lr} 34$ resistance allele was present in 21 cultivars, representing a frequency of $45 \%$ (Table 1).

Molecular analyses showed that the frequency of the resistance allele of the gene $\operatorname{Lr} 34$, among 47 Romanian winter wheat cultivars, released since 1933, increased from $0 \%$, for the cultivars released before the establishment of the Fundulea Institute (in 1957), to 10\% in cultivars released before 1989 , and to $90 \%$ in modern cultivars, including the cultivars currently grown. Among the 47 analyzed Romanian winter wheat breeding lines 37 (79\% frequency) were found homozygous for $\operatorname{Lr} 34$ resistance allele, 3 lines were heterozygous or heterogenic and only 7 lines carried the $\operatorname{Lr} 34$ susceptibility allele. It is interesting to note that the frequency of the resistance allele of $L r 34$ in the breeding lines is higher than $75 \%$, which suggests that the selection pressure favored the maintenance of a high frequency of this allele. 


\section{Discussion}

The introduction of molecular characterization of the gene $\operatorname{Lr} 34$ allele status allows a more effective selection, because it can be applied at the early plant development stage and in absence of Puccinia triticina. The mostly widely used molecular marker for evaluation and selection of Lr34 gene has been csLV34 (Kolmer et al. 2008; Vanzetti et al. 2011; Kadkhodaei et al. 2012), but functional markers tend to replace this marker (Karelov et al. 2011; McCallum et al. 2012; Dakouri et al. 2013). Our results also suggest that functional markers are more informative than csLV34 marker.

Because the resistance allele of $\mathrm{Lr} 34$ gene is present in almost all cultivars released in recent years, at present more than $60 \%$ of the area planted with wheat in Romania has been in recent years partially protected against the leaf rust attack by a gene that has proven to be durable (Table 3). The high frequency of the resistance allele of the $\mathrm{Lr} 34$ gene can be explained on the basis of pedigrees of cultivars created at Fundulea (Fig. 4). The cultivars Lovrin 32 and Flamura 80, selected from the cross between the Russian variety Ranniaia 12 and Nadadores 63 a Mexican variety, both carrying the resistance allele, was the main source of this allele.

Using molecular marker csLV34, Kolmer et al. (2008) found the origin of the Lr34 gene in wheat cultivars from North and South America, CIMMYT, Australia and Russia was tracked back to the cultivars Mentana and Ardito developed in Italy by Nazareno Strampelli in the early 1900s. Both Ranniaia 12 and Nadadores 63 have Mentana in their

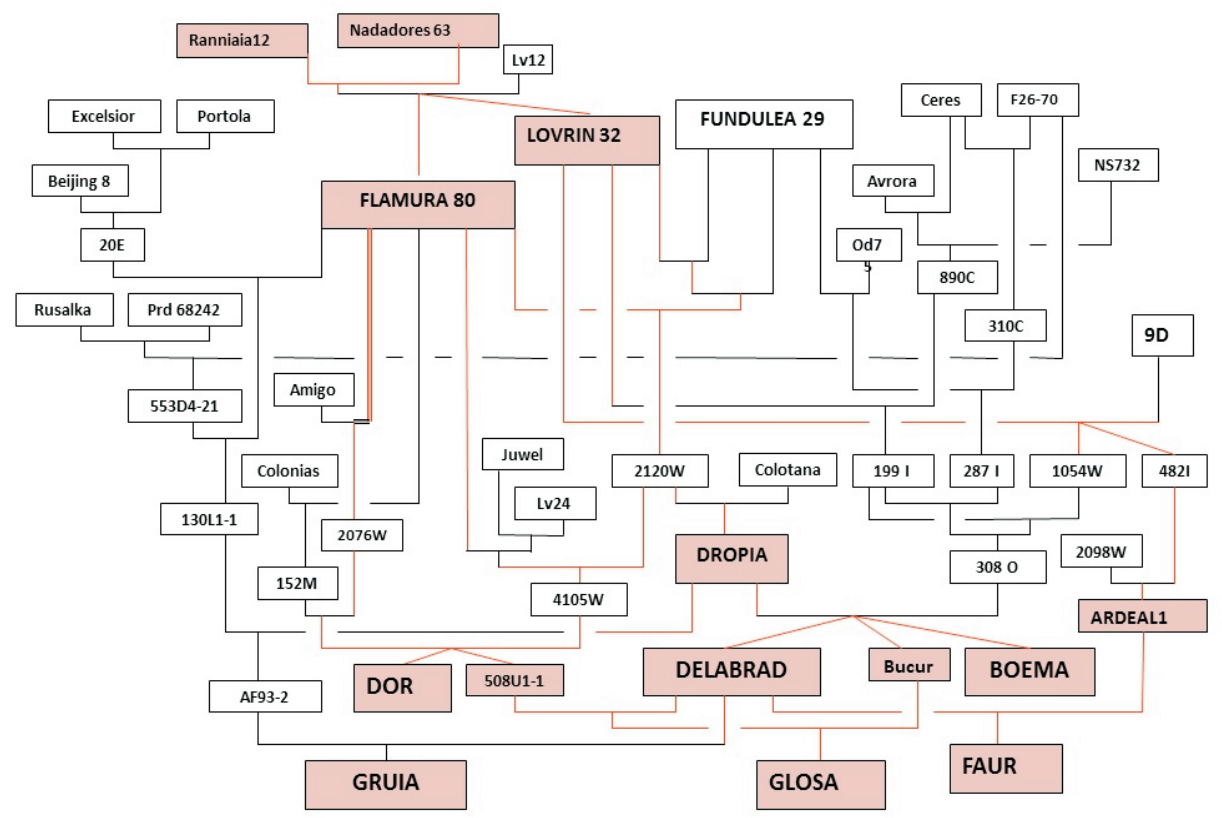

Figure 4. Origin of $\operatorname{Lr} 34$ gene in Romanian winter wheat cultivars 


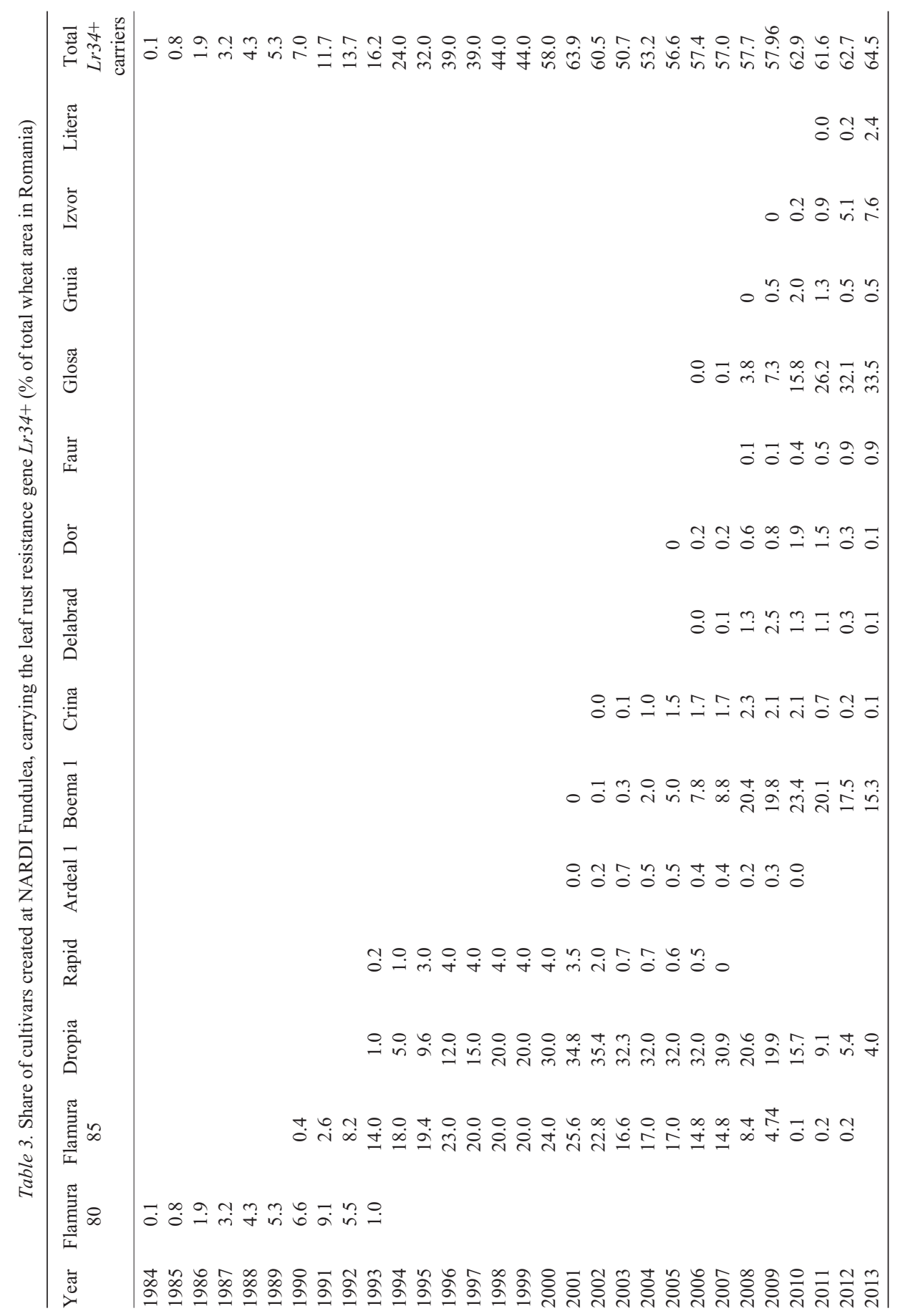


ancestry. The progenies of Flamura 80 and Lovrin 32 have been extensively used in the breeding program especially at Fundulea, as a source of genes for semi-dwarf trait and good grain filling.

In this way adult plant resistance given by $L r 34$ gene could be fixed in the breeding program by continuous selection for a good behavior against leaf rust attack in the field, and also by the presence of phenotypic markers "leaf tip necrosis", associated with this leaf rust resistance allele.

\section{Conflict of interests}

The authors declare that there is no conflict of interests regarding the publication of this paper.

\section{Acknowledgements}

Authors are thankful to Dr. Beat Keller and Dr. Simon Krattinger from Institute of Plant Biology, Molecular Plant Biology/Phytopathology Department, Zurich, Switzerland, for their kindness to provide us seeds from Chinese Spring cultivars and nulli-tetrasomic N7DT7A line and for their support.

The present work was funded through the UEFISCDI ANCS (National Authority for Scientific Research) Research Project PCCA 99/2012 "Phenotypic and molecular approaches to develop durable adult plant (slow-rusting, race non-specific) resistance to leaf rust (Puccinia triticina) in wheat (Triticum aestivum)".

\section{References}

Anonymous 2014. Producția agricolă vegetală la principalele culturi, în anul 2013 (Agricultural production of main crops in 2013). http://www.insse.ro/cms/files/statistici/comunicate/com_anuale/Prod_veg/prod_ veg_r13 (in Romanian)

Dakouri, A., McCallum, B.D., Walichnowski, A.Z., Cloutier, S. 2010. Fine-mapping of the leaf rust Lr34 locus in Triticum aestivum (L.) and characterization of large germplasm collections support the ABC transporter as essential for gene function. Theor. Appl. Genet. 121:373-384.

Dakouri, A., McCallum, B.D., Radovanovic, N., Cloutier, S. 2013. Molecular and phenotypic characterization of seedling and adult plant leaf rust resistance in a world wheat collection. Mol. Breeding 32:663-677.

Dyck, P.L. 1977. Genetics of leaf rust reaction in three introductions of common wheat. Can. J. Genet. Cytol. 19:711-716.

Dyck, P.L. 1987. The association of a gene for leaf rust resistance with the chromosome 7D suppressor of stem rust resistance in common wheat. Genome 29:467-469.

German, S.E., Kolmer, J.A. 1992. Effect of gene Lr34 in the enhancement of resistance to leaf rust of wheat. Theor. Appl. Genet. 84:97-105.

Herrera-Foessel, S.A., Lagudah, E.S., Huerta-Espino, J., Hayden, M.J., Bariana, H.S., Singh, D., Singh, R.P. 2011. New slow-rusting leaf rust and stripe rust resistance genes Lr67 and Yr46 in wheat are pleiotropic or closely linked. Theor. Appl. Genet. 122:239-249.

Herrera-Foessel, S.A., Singh, R.P., Huerta-Espino, J., Rosewarne, G.M., Periyannan, S.K., Viccar, L., Calvo-Salazar, V., Lan, C., Lagudah, E.S. 2012. Lr68: A new gene conferring slow rusting resistance to leaf rust in wheat. Theor. Appl. Genet. 124:1475-1486.

Hiebert, C.W., Thomas, J.B., McCallum, B.D., Humphreys, G.D., DePauw, R.M., Hayden, M.J., Mago, R., Schnipenkoetter, W., Hayden, M. 2010. An introgression on wheat chromosome 4DL in RL6077

Cereal Research Communications 43, 2015 
(Thatcher*6/PI 250413) confers adult plant resistance to stripe rust and leaf rust (Lr67). Theor. Appl. Genet. 121:1083-1091.

Kadkhodaei, M., Dadkhodaie, A., Taghi Assad, M., Heidari, B., Mostowfizadeh-Ghalamfarsa, R. 2012. Identification of the leaf rust resistance genes $\operatorname{Lr} 9, \operatorname{Lr} 26, \operatorname{Lr} 28, \operatorname{Lr} 34$, and $\operatorname{Lr} 35$ in a collection of Iranian wheat genotypes using STS and SCAR markers. J. Crop Sci. Biotech. 15:267-274.

Karelov, A.V., Pirko, Ya.V., Kozub, N.A., Sozinov, I.A., Pirko, N.N., Litvinenko, N.A., Lyfenko, S.F., Koliuchii, V.T., Sozinov, A.A. 2011. Identification of the allelic state of the $L r 34$ leaf rust resistance gene in soft winter wheat cultivars developed in Ukraine. Cytology and Genetics 45:271-276.

Kloppers, F.J., Pretorius, Z.A. 1997. Effects of combinations amongst genes Lr13, Lr34 and Lr37 on components of resistance in wheat to leaf rust. Plant Pathol. 46:737-750.

Kolmer, J.A., Singh, R.P., Garvin, D.F., Viccars, L., William, H.M., Huerta-Espino, J., Ogbonnaya, F.C., Raman, H., Orford, S., Bariana, H.S., Lagudah, E.S. 2008. Analysis of the Lr34/Yr28 rust resistance region in wheat germplasm. Crop Sci. 48:1841-1852.

Krattinger, S.G., Lagudah, E.S., Spielmeyer, W., Singh, R.P., Huerta-Espino, J., McFadden, H., Bossolini, E., Selter, L.L., Keller, B. 2009. A putative ABC transporter confers durable resistance to multiple fungal pathogens in wheat. Science 323:1360-1363.

Lagudah, E.S. 2011. Molecular genetics of race non-specific rust resistance in wheat. Euphytica 179:81-91.

Lagudah, E.S., Krattinger, S.G., Herrera-Foessel, S., Singh, R.P., Huerta-Espino, J., Spielmeyer, W., Brown-Guedira, G., Selter, L.L., Keller, B. 2009. Gene-specific markers for the wheat gene Lr34/Yr18/Pm38 which confers resistance to multiple fungal pathogens. Theor. Appl. Genet. 119:889-898.

Lagudah, E.S., McFadden, H., Singh, R.P., Huerta-Espino, J., Bariana, H.S., Spielmeyer, W. 2006. Molecular genetic characterization of the $\operatorname{Lr} 34 / \mathrm{Yr} 18$ slow rusting resistance gene region in wheat. Theor. Appl. Genet. 114:21-30.

Li,T., Bai, G.H., Gu, S.L. 2012. A combination of leaf rust resistance gene Lr34 and lesion mimic gene $l m$ significantly enhances adult plant resistance to Puccinia triticina in wheat. Chin. Sci. Bull. 57:2113-2119.

Lillemo, M., Asalf, B., Singh, R.P., Huerta-Espino, J., Chen, X.M., He, X.H., Bjornstad, Å. 2008. The adult plant rust resistance loci $\operatorname{Lr} 34 / Y r 18$ and $L r 46 / Y r 29$ are important determinants of partial resistance to powdery mildew in bread wheat line Saar. Theor. Appl. Genet. 116:1155-1166.

Lillemo, M., Joshi, A.K., Prasad, R., Chand, R., Singh, R.P. 2013. QTL for spot blotch resistance in bread wheat line Saar co-locate to the biotrophic disease resistance loci $L r 34$ and $L r 46$. Theor. Appl. Genet. 126:711-719.

McCallum, B.D., Humphreys, D.G., Somers, D.J., Dakouri, A., Cloutier, S. 2012. Allelic variation for the rust resistance gene $\operatorname{Lr} 34 / \mathrm{Yr} 18$ in Canadian wheat cultivars. Euphytica 183:261-274.

Purnhauser, L., Fónad, P., Kótai, E., Csősz, M. 2011. Disease resistance of Hungarian and Romanian wheat cultivars observed by field and laboratory methods. "Strong wheat" Proc. Closing Conference. Timisoara, Romania, pp. 11-16.

Singh, D., Mohler, V., Park, R.F. 2013. Discovery, characterisation and mapping of wheat leaf rust resistance gene $\operatorname{Lr} 71$. Euphytica 190:131-136.

Singh, R., Herrera-Foessel, S.A., Huerta-Espino, J., Bariana, H.S., Bansal, U., McCallum, B.D., Hiebert, C.W., Bhavani, S., Singh, S., Lan, C., Lagudah, E.S. 2012. Lr34/Yr18/Sr57/Pm38/Bdv1/Ltn1 confers slow rusting, adult plant resistance to Puccinia graminis tritici. In: Proc. $13^{\text {th }}$ Cereal Rust and Powdery Mildew Conference. Beijing, China, p. 173.

Singh, R.P. 1992. Association between gene Lr34 for leaf rust and leaf tip necrosis in wheat. Crop Sci. 32:874-878.

Singh, R.P., Mujeeb-Kazi, A., Huerta-Espino, J. 1998. Lr46: A gene conferring slow-rusting resistance to leaf rust in wheat. Phytopathol. 88:890-894.

Singh, R.P., Huerta-Espino, J. 2003. Effect of leaf rust resistance gene Lr34 on components of slow rusting at seven growth stages in wheat. Euphytica 129:371-376.

Spielmeyer, W., McIntosh, R.A., Kolmer, J., Lagudah, E.S. 2005. Powdery mildew resistance and Lr34/Yr18 genes for durable resistance to leaf and stripe rust cosegregate at a locus on the short arm of chromosome 7D of wheat. Theor. Appl. Genet. 111:731-735.

Vanzetti, L.S., Campos, P., Demichelis, M., Lombardo, L.A., Aurelia, P.R., Vaschetto, L.M., Bainotti, C.T., Helguera, M. 2011. Identification of leaf rust resistance genes in selected Argentinean bread wheat cultivars by gene postulation and molecular markers. Electronic J. Biotechnology http://www.ejbiotechnology.info DOI: $10.2225 /$ vol14-issue3-fulltext-14. 